\title{
Improvement of Nutritional Value of Cocoa Pod Husk Fermented with Aspergillus spp. and Two Levels of Urea and Ammonium Sulphate
}

\author{
Rakhmani SIW ${ }^{1}$, Purwadaria $T^{2}$ \\ ${ }^{1}$ Indonesian Research Institute for Animal Production. Jl. Veteran III, Ciawi Bogor, West Java 16720, Indonesia \\ ${ }^{2}$ Atma Jaya Catholic University \\ E-mail: susanawijaya@yahoo.com.au
}

(received 19-06-2017; revised 05-09-2017; accepted 11-09-2017)

\begin{abstract}
ABSTRAK
Rakhmani SIW, Purwadaria T. 2017. Peningkatan nilai gizi kulit buah kakao yang difermentasi menggunakan Aspergillus spp. dengan dua tingkat urea dan amonium sulfat. JITV 22(3): 101-113. DOI: http://dx.doi.org/10.14334/jitv.v22i3.1670

Kulit buah kakao melimpah sebagai produk limbah perkebunan kakao dan berpotensi sebagai bahan pakan tetapi memiliki nilai gizi rendah. Untuk meningkatkan nilai gizi kulit buah kakao (CPH), telah dilakukan proses biologis melalui fermentasi substrat padat menggunakan Aspergillus oryzae dan Aspergillus niger serta penambahan dua dosis (N1 dan N2) nitrogen dalam campuran mineral. Produknya adalah Fermented Cocoa Pod Husk (FCPH).Kandungan protein meningkat dari $50 \mathrm{~g} / \mathrm{kg}$ sebelum fermentasi menjadi $133,8 \mathrm{~g} / \mathrm{kg}$ untuk N1 fermentasi menggunakan A. niger dan $150 \mathrm{~g} / \mathrm{kg}$ menggunakan A. oryzae. Kandungan protein sejati adalah 99,8 dan $93,5 \mathrm{~g} / \mathrm{kg}$ untuk perlakuan N1 dan N2 (A. niger); 119 dan 104,1 g/kg untuk perlakuan N1 dan N2 (A. oryzae). Aspergillus niger menunjukkan keunggulan dalam hal produksi enzim bila dibandingkan dengan Aspergillus oryzae. Aktivitas mannanase pada produk fermentasi A. niger dengan dosis N1 mencapai $2654 \mathrm{U} / \mathrm{g}$ dan A.oryzae adalah $1122 \mathrm{U} / \mathrm{g}$. Bahan kering dan kecernaan protein masing-masing untuk FCPH A. niger adalah 47 dan $57 \%$ dan FCPH A. oryzae adalah 52 dan 62\%. Proses fermentasi kulit buah coklat menghasilkan produk yang sangat potensial sebagai pakan alternatif dengan kadar protein lebih tinggi dan mengandung enzim mannanase.
\end{abstract}

Kata Kunci: Kulit Buah Coklat, Aspergillus Niger, Aspergillus Oryzae, Mannanase, Selulase

\section{ABSTRACT}

Rakhmani SIW, Purwadaria T. 2017. Improvement of nutritional value of cocoa pod husk fermented with Aspergillus Spp. and two levels of urea and ammonium sulphate. JITV 22(3): 101-113. DOI: http://dx.doi.org/10.14334/jitv.v22i3.1670

Cocoa pod husk is abundant as a waste product of cocoa plantation and potential as feed ingredient but has low nutritional value. To increase the nutritive value of cocoa pod husk ( $\mathrm{CPH}$ ), biological process through solid substrate fermentation using Aspergillus oryzae and Aspergillus niger and addition of two doses (N1 and N2) of nitrogen mixture had been done. The product is Fermented Cocoa Pod Husk (FCPH). Protein content increased from $50 \mathrm{~g} / \mathrm{kg}$ before fermentation to $133.8 \mathrm{~g}$. kg-1 for $\mathrm{N} 1$ for A. niger and $150 \mathrm{~g} / \mathrm{kg}$ using A. oryzae. True protein were 99.8 and $93.5 \mathrm{~g} / \mathrm{kg}$ for $\mathrm{N} 1$ and N2 treatments (A. niger); 119 and $104.1 \mathrm{~g} / \mathrm{kg}$ for N1 and N2 treatments $(A$. oryzae). Aspergillus niger showed a superiority in term of enzymes production when compared to Aspergillus oryzae. Mannanase activy in A. niger fermentation product with $\mathrm{N} 1 \mathrm{dose}$ reached up to $2654 \mathrm{U} / \mathrm{g}$ and A.oryzae was $1122 \mathrm{U} / \mathrm{g}$. Dry matter and protein digestibility for A. niger FCPH were 47 and 57\% and A. oryzae FCPH were 52 and $62 \%$ repectively. Fermentation processed of $\mathrm{CPH}$ yield a product that very potential as an alternative feed with higher in protein content and contain mannanase enzyme.

Key Words: Cocoa Pod Husk, Aspergillus niger, Aspergillus oryzae, Mannanase, Cellulose

\section{INTRODUCTION}

In animal husbandry, the feed comprises the highest expense and appropriate feed quality nutrition is important. Shortage of feedstuff is also one of several factors in animal production in Indonesia, especially since most of feed materials (such as corn and soybean meal) are imported. Therefore, in addition to conventional feed ingredients, uncommon feed ingredients such as of agriculture by-product would be 
advantage to solve feed insufficiency. Indonesia's cocoa crop is one of the largest estates after palm oil. Indonesian Cocoa plantation (Theobroma cacao L.) area currently is reached $1,745,789$ hectares and is largely possessed by smallholders with a total production of 903.092 tons/year (Estate Statistic 20082012). It will be 695,467 tons of fresh $\mathrm{CPH}$ (equivalent to 893,092 dried material) by-product. Waste and byproducts of cocoa fruit itself is more than half of worldwide cocoa production and estimated at 3.53 million tons (World Cocoa Foundation 2010). Indonesia, including the 20 largest cocoa producing countries and was ranked the $3^{\text {rd }}$ after Ghana and Ivory Coast.

Cocoa pod husks has been investigated as an alternative feed and had been fed without toxic effects to cattle in quantities up to $7 \mathrm{~kg}$ per day. For dairy cows, pod meal seems to be comparable in value to corncob meal. Rations containing cocoa pod meal have a lower feed efficiency for beef cattle, but this will be compensated by the larger intake (FAO 2002). A digestion study with sheep, was carried out to determine the effect of graded dietary cocoa-pod levels between 0 and $75 \%$ in feed, the apparent digestibility of cocoa-pod by sheep was also estimated and reported that sheep digested only $23 \%$ dry matter and $51 \%$ crude protein of the pod (Smith \& Adegbola 1985). Processed-CPH was used as feed material and can replace conventional feed ingredients such as corn and soybean meal and regarded as alternative animal feed (Sobamiwa \& Longe 1993; Sobamiwa 1998).

Biological processes can improve the nutritional composition and utilization of $\mathrm{CPH}$ and would be more advantage as feed. Fermentation process using cellulolytic fungi could be used to overcome high crude fiber content in $\mathrm{CPH}$, which is as a constraint factor for direct utilization of $\mathrm{CPH}$ especially in poultry diet. Processing $\mathrm{CPH}$ had been reported such as $\mathrm{CPH}$-silage (North Sumatera and Lampung provinces), and fermentation process using Aspergillus niger (South Sulawesi and Bali provinces) has done, but there is no detailed information on the nutritional value such as the digestibility, enzymes activities and true protein of the resulting product. It was reported an increase in protein content of $9 \%$ to $12 \%$ was achieved after fermentation with A. niger (Haryati \& Sutikno 1994).

Fungi such as Aspergillus spp. produce several enzymes which is important to elevate feed digestibility. When $\mathrm{CPH}$ was fermented using this fungi, the final product can be fed to livestock without addition of enzymes. It was reported that minerals and inorganic nitrogen can increase cell growth and correlated on enzymes and protein productions in fermentation of cassava by-product using Aspergillus spp (Kompiang 1994). In this study, an experiment had been done to investigate the nutritive value of fermented $\mathrm{CPH}$ product by Aspergillus oryzae and
Aspergillus niger. Solid substrate fermentation method was applied to steamed CPH with two levels of ureaammonium sulphate mixtures $(0,5 \%$ urea $+1 \%$ ammonium sulphate and $1 \%$ urea+ $2 \%$ ammonium sulphate). Proximate composition, cellulolytic enzymes (mannanase and cellulase) activities, dry matter and protein digestibility (in vitro) were also examined in the fermented product.

\section{MATERIALS AND METHODS}

\section{Preparation of CPH and Aspergillus inoculums}

Fresh CPH were obtained from Nusantara Plantation VIII-Public Company (PTPN VIII) at Rajamandala District- West Java, and processed at the IRIAP. The husks were cleaned, chopped into smaller pieces, solardried to a moisture content of ca. $10 \%$ and ground. The dried husk were then stored at room temperature until used. Fungi Aspergillus oryzae GS66 was previously isolated from garlic seed) whereas $A$. niger was obtained from IRIAP collection. Dried-spore inoculums of $A$. oryzae and $A$. niger were prepared by growing the fungi in in cooked-rice substrate for 3-4 days, dried at $40^{\circ} \mathrm{C}$, ground and stored at $4^{\circ} \mathrm{C}$ (Purwadaria et al. 1994).

\section{Substrates and fermentation}

Three kind of treatments ( $\mathrm{C}, \mathrm{N} 1$, and N2) were applied. Treatment $\mathrm{C}$ as control, substrate $+50 \mathrm{~g}$ rice bran $/ \mathrm{Kg}$. The composition of minerals mixture for $1 \mathrm{~kg}$ dried substrate as shown as in Table 1. Distilled water was first added to the ground dried $\mathrm{CPH}$ substrate to make water content of about $60 \%$ then steamed for 30 minutes. After cooling to about $40^{\circ} \mathrm{C}$ the minerals and 8 $\mathrm{g}$ of inoculum were added. The cultures were incubated at room temperature.

Table 1. Mineral Content in Treatments

\begin{tabular}{lccc}
\hline \hline \multirow{2}{*}{ Minerals/other materials } & \multicolumn{3}{c}{ Treatments } \\
\cline { 2 - 4 } Trisuperphosphate (TSP) & $\mathrm{C}$ & $\mathrm{N} 1$ & $\mathrm{~N} 2$ \\
$\mathrm{MgSO} 4.7 \mathrm{H} 2 \mathrm{O}$ & 0 & 2.40 & 2.40 \\
$\mathrm{FeSO} 4.6 \mathrm{H} 2 \mathrm{O}$ & 0 & 0.10 & 0.10 \\
$\mathrm{KCl}$ & 0 & 3.80 & 3.80 \\
$\mathrm{CaCl} 2.2 \mathrm{H} 2 \mathrm{O}$ & 0 & 0.13 & 0.13 \\
(NH4)2SO4 & 0 & 10.00 & 20.00 \\
Urea & 0 & 5.00 & 10.00 \\
Rice Bran & 50 & 27.32 & 12.32 \\
\hline
\end{tabular}




\section{Laboratory analysis}

All chemical and digestibility analysis were carried out at the Analytical Services and Feed Technology Laboratories, Indonesian Research Institute for Animal Production. Proximate analysis (Crude protein, fat, fiber, ash), Calcium and Phosphor, Energy and van Soest fiber (NDF, ADF, Lignin) were performed in both optimally fermented and unfermented CPH. Optimum fermentation period was determined based on protein content reached in particular time of incubation and was determined using modified Lowry method (Lowry et al. 1951).To obtain total protein concentration, $1 \mathrm{ml}$ of $2 M$ $\mathrm{NaOH}$ was added to $0.1 \mathrm{~g}$ of sample then heated for 30 min at $100^{\circ} \mathrm{C}$. After dilution ten-fold in destilled water, protein concentration was measured by a standard Lowry method using bovine serum albumin (BSA) as a standard.

\section{In vitro rumen-pepsin digestibility}

Subsequently, 0.2-0.4 g of experimental samples were weight out in an $100 \mathrm{ml}$-in vitro tubes, $0.2-0.4 \mathrm{~g}$ samples from laboratory standards (grass hay) were added to 2 tubes and 2 tubes were used as blanks for the experiments. In each tube, $25 \mathrm{~mL}$ of a RumenMcDougall buffer mixture was added under purging with $\mathrm{CO}_{2}$ and caped tightly with a rubber stopper/gasrelease port. Samples were incubated for $48 \mathrm{~h}$ in a water bath at $39^{\circ} \mathrm{C}$, followed by further digestion in an acidpepsin solution containing $6.6 \mathrm{~g}$ pepsin $/ \mathrm{L} \quad 0.1 \mathrm{~N}$ hydrochloric acid (Catalog P6887-SIGMA) (25 mL of acid-pepsin solution was added to each tube) for $48 \mathrm{~h}$ in water bath at $39^{\circ} \mathrm{C}$. All tubes were mixed by swirling (Vortex Mixer) them at 2, 4, 8, and $36 \mathrm{~h}$, after adding the rumen-buffer mixture and at 2,4 , and $6 \mathrm{~h}$ after adding acid-pepsin. After completion of the digestion, contents were filtered into pre-weighed standard coarse fritted disk Gooch crucibles (G2) under mild vacuum, dried at $105^{\circ} \mathrm{C}$ for at least $12 \mathrm{~h}$, weighed for determination of DM. Protein content of in vitro sediment was determined for protein digestibility calculation (Marais \& Evenwell 1983).

\section{True protein analysis}

True protein was measured according Marais \& Evenwell (1983) by TCA-precipitation with slightly modification. Sample was finely ground and weight out $(0.5-1 \mathrm{~g})$ into a $50 \mathrm{ml}$ tube with caped, add $15 \mathrm{ml}$ of water and incubate $10 \mathrm{~min}$ in a boiling water-bath, cooled and added $15 \mathrm{ml}$ of $10 \%$ TCA and then shake in a medium speed using Griffin Flask Shaker for $20 \mathrm{~min}$ and then left for an hour at $4{ }^{\circ} \mathrm{C}$. Mixture was centrifuged at $3000 \mathrm{rpm}$ for $10 \mathrm{~min}$. The pellet was rinsed twice with $5 \mathrm{ml} 1 \%$ TCA and protein content of the precipitate was determined.

\section{Enzymes activity}

Mannanase activity was measured using locust gum $\left(0.5 \mathrm{~g} . \mathrm{Kg}^{-1}\right)$ as substrate and followed the procedure as described by PURWADARIA et al. (2003). Enzymes was extracted from the sample $(0.5 \mathrm{~g}-1 \mathrm{~g})$ with $10 \mathrm{ml}$ of acetate buffer $\mathrm{pH} 5.8$ and mixed for $30 \mathrm{~min}$. The mannanase activity was measured as the amount of reducing sugar released from the substrate. Reducing sugar was determined by using the 3,4-dinitro salicylic acid (DNS) method of Miller (1959) and mannose was used as standard. One unit mannanase activity was defined as the amount of enzyme that required to release $1 \mu$ mole of glucose $\min ^{-1} \mathrm{ml}^{-1}$ under assay condition

Cellulase assays are carried out using the carboxy methyl cellulose (CMC) as substrate. Enzymes solution was obtained by extraction of sample $(0.5-1 \mathrm{~g})$ in $25 \mathrm{ml}$ of $0.05 \mathrm{M}$ citrate buffer $\mathrm{pH} 4.8$. The amount of released reducing sugar was quantified using the 3,4-dinitro salicylic acid (DNS) method of MILLER (1959) and glucose was used as standard for determining enzyme activity. One unit of enzyme activity is defined as the amount of enzyme required to release $1 \mu$ mole of glucose $\mathrm{min}^{-1} \mathrm{ml}^{-1}$ under assay condition (Miller 1959).

\section{Statistical analysis}

Data were subjected to a one-way analysis of variance (ANOVA).

\section{RESULTS AND DISCUSSION}

Growth of A. niger and A. oryzae on CPH substrate during fermentation period is presented in Table 2. In the first 24 hours mycelium growth was undetected. Mycelia formation was detected in the $2^{\text {nd }}$ day of incubation of both Aspergillus niger and A. oryzae along with young spores formation scattered for about $10 \%$ that can be observed from the substrate surface. For treatment using lower inorganic nitrogen addition (N1), mycelia formation was tend to be slower than higher inorganic nitrogen treatment (N2).

Mycelia became thick and fungal hyphae had been penetrated and bind the substrate was clear in the third day of incubation and a distinction spores color for both species were detected. It was hard to report the difference between inorganic treatments in term of mycelia formation in this stage and in the next day beyond fermentation period. Mycelia thickness was remained in the fourth day and older spore formation 
Table 2. Visual observation of fungi growth on $\mathrm{CPH}$ substrate during fermentation periods

\begin{tabular}{|c|c|c|c|c|}
\hline \multirow[t]{2}{*}{ Incubation Period (day) } & \multicolumn{2}{|c|}{ Aspergillus niger } & \multicolumn{2}{|c|}{ Aspergillus oryzae } \\
\hline & N1 & $\mathrm{N} 2$ & N1 & $\mathrm{N} 2$ \\
\hline 1 & $*$ & $*$ & $*$ & $*$ \\
\hline 2 & ++ & ++ & ++ & ++ \\
\hline 3 & +++ & ++++ & +++ & ++++ \\
\hline 4 & ++++ & ++++ & ++++ & ++++ \\
\hline 5 & $* * *$ & $* * *$ & $* * *$ & $* * *$ \\
\hline
\end{tabular}

*Mycelia growth undetected, raised in temperature was observed

++ Thin covering mycelia, tiny spores

+++ Penetration of mycelia

++++ mycelia covering all over substrate

****spores covering all over substrate surface

almost completely found in both species. In the $5^{\text {th }}$ day, spores were found all over the substrate surface.

In every process of fermentation, dry matter loss of the substrate is inevitable. Dry matter loss of $\mathrm{CPH}$ during incubation is presented in Figure 1. In the process, substrate was added water up to $60 \%$ water content. It was reported that water holding between 60 $65 \%$ was suitable for solid substrate fermentation (Chalall 1985; Singhania et al. 2006). In this experiment we found out that the maximum capacity of water holding for $\mathrm{CPH}$ was in the ratio of $\mathrm{CPH}$-water 100 : 120 . The water content was $600 \mathrm{~g} / \mathrm{kg}$, however, when it was higher than that ratio, water was not held perfectly and was flowing out from the substrate. It was reported that $70 \%$ moisture level in the substrate prevents oxygen penetration and facilitates the contamination, whereas the low moisture level inhibits the growth, enzyme activity and accessibility to nutrients (Mekala et al. 2008). Dry matter loss profiles for both A. niger and $A$. oryzae were similar, all below $300 \mathrm{~g} / \mathrm{kg}$, and for control group (without addition of minerals), DM loss was detected below $150 \mathrm{~g} / \mathrm{kg}$. The moisture level of culture medium affects the physiology of the microorganism.

It was a significant increased $(\mathrm{P}<0.05)$ in crude protein content of fermented $\mathrm{CPH}$ when compared with the control group. The highest protein content in the fermentation product of $A$. niger was shown in the $4^{\text {th }}$ day of incubation (Figure 2). Protein content in N1 treatment was $133.8 \mathrm{~g} / \mathrm{kg}$ and $\mathrm{N} 2$ treatment $131.9 \mathrm{~g} / \mathrm{kg}$ statistically not significantly different When $\mathrm{CPH}$ was fermented using $A$. oryzae, the highest protein content was detected at the $3^{\text {rd }}$ day of incubation $(154 \mathrm{~g} / \mathrm{kg}$ for $\mathrm{N} 1$ and $148.8 \mathrm{~g} / \mathrm{kg}$ for $\mathrm{N} 2$ ). The $\mathrm{CP}$ in the A. oryzae FCPH statistically not significantly different between $\mathrm{N} 1$ and N2. It had been reported that fungal fermentations on several agro-byproduct such as cassava by-product, coffee husk, corn bran and rice bran have also reported similar increases in protein content (Leifa et al. 2001; Iyayi \& Aderolu 2004). Solid-state fermentation of $\mathrm{CPH}$ using Rhizopus stolonifer LAU was reported an increase in $\mathrm{CPH}$ protein up to $95 \%$ (Lateef et al. 2008). The increased in protein content of $\mathrm{CPH}$ fermented by A. niger and A. oryzae could be due to bioconversion of some of soluble carbohydrates in the substrate into mycelia protein or single cell protein (SCP) by the growing fungus (Iyayi 2004). It was also reported that the growth and sporulation of the fungus Aspergillus niger is influenced by the level of nitrogen (from ammonium sulfate and urea) in the culture medium (Swe et al. 2009). However, in this experiment, in the higher of substrate-nitrogen level (N2) CP was not significantly different as of lower nitrogen level (N1). It showed that nitrogen level that supposed to be used by fungi for growing not necessarily high but in some point it will be efficient. Nitrogen level of N1 treatment showed efficiency in using inorganic fertilizer for fermentation process. It will open an opportunity for using more $\mathrm{CPH}$ fermentation product as non-ruminant feed ingredient without worried to urea toxic effect. 


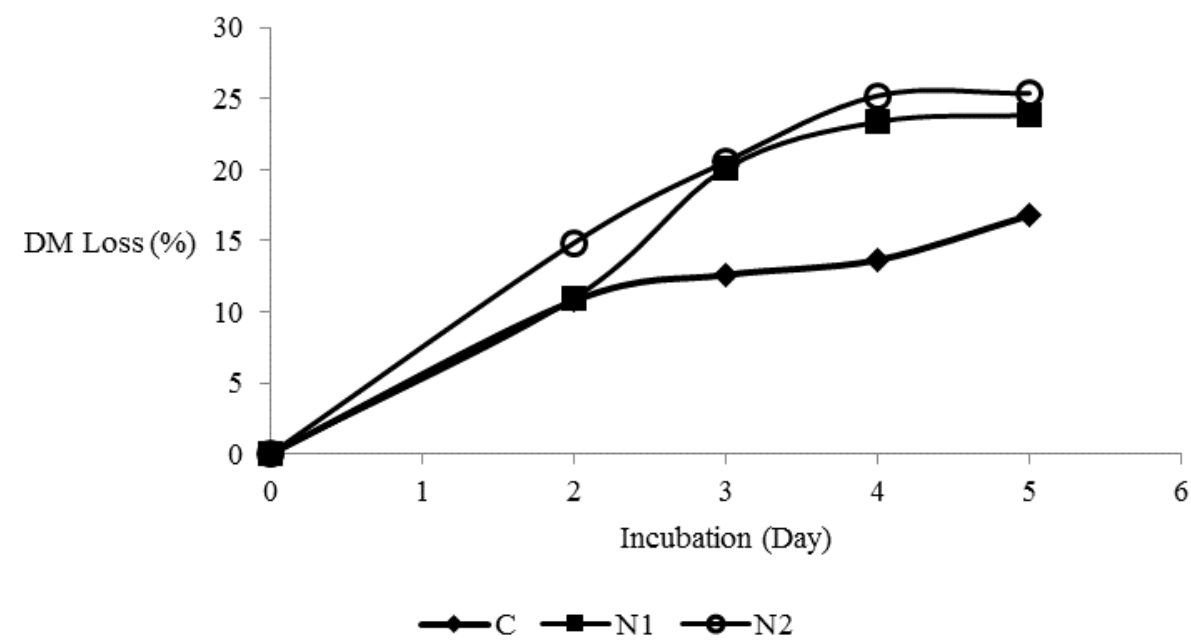

A. oryzae

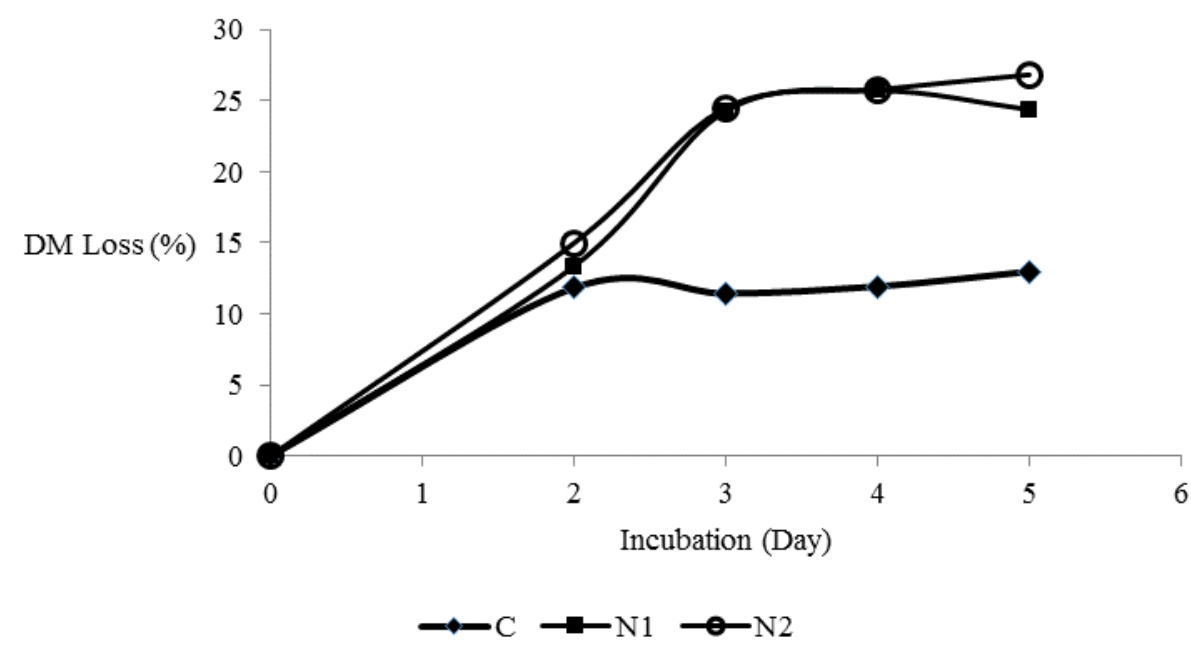

Figure 1. Dry matter loss on CPH substrate fermented with A. niger and A. oryzae.

Total protein analysis with KJELDAHL digestion measures crude protein, where the total nitrogen content of sample is multiplied by 6.25 to express the results on a protein equivalent basis. The total amount of nitrogen in feed/feed ingredient however, comes from both protein and non-protein nitrogen sources. True protein reflects only the nitrogen associated with protein and does not include the nitrogen from non-protein sources. The true protein was lower than crude protein content and shown in Figure 3. The true protein content in control treatment was between 33.7 and $51.11 \mathrm{~g} / \mathrm{kg}$, whereas in fermentation product were $99.8 \mathrm{~g} / \mathrm{kg}$ and $93.5 \mathrm{~g} / \mathrm{kg}$ for $\mathrm{N} 1$ and $\mathrm{N} 2$ treatments respectively (A. niger) and $119.0 \mathrm{~g} / \mathrm{kg}$ and $104.1 \mathrm{~g} / \mathrm{kg}$ both for $\mathrm{N} 1$ and $\mathrm{N} 2$ treatments (A. oryzae) respectively. The true protein content of fermentation products of $A$. oryzae significantly higher than $A$. niger in both nitrogen levels. It is important to measure the true protein instead of crude protein due to inorganic nitrogen that was added to boost the growth of fungi in the beginning of fermentation will give inaccurate in crude protein calculation. In this experiment, the non-protein fraction in fermented $\mathrm{CPH}$ was calculated between 23 and $30 \%$. Residual inorganic nitrogen is included in this fraction. Inorganic nitrogen such as from ammonium sulfate or urea will affect negatively especially in non-ruminant animals, but ruminant can tolerate urea and is used by rumen microbe for protein synthesis.

Proximate analysis of fermented product is presented in Table 3. Control treatment was ground $\mathrm{CPH}$, which was not added any mineral mixture and directly fermented using A. niger (AN) and A. oryzae 
A. niger

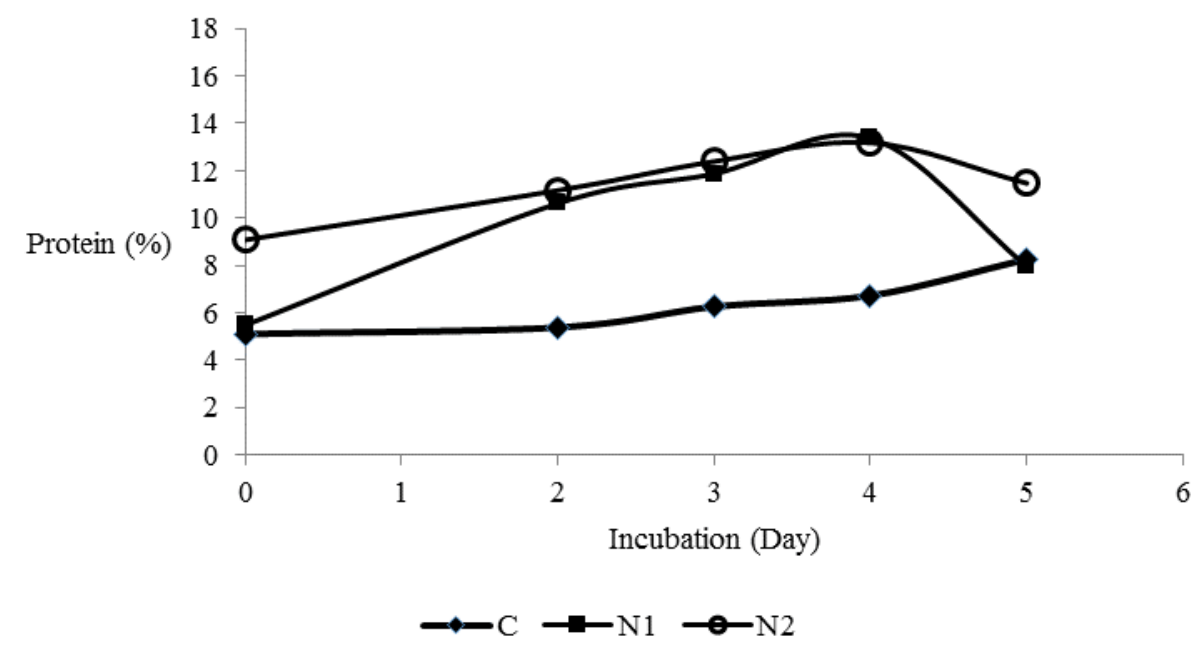

A. oryzae

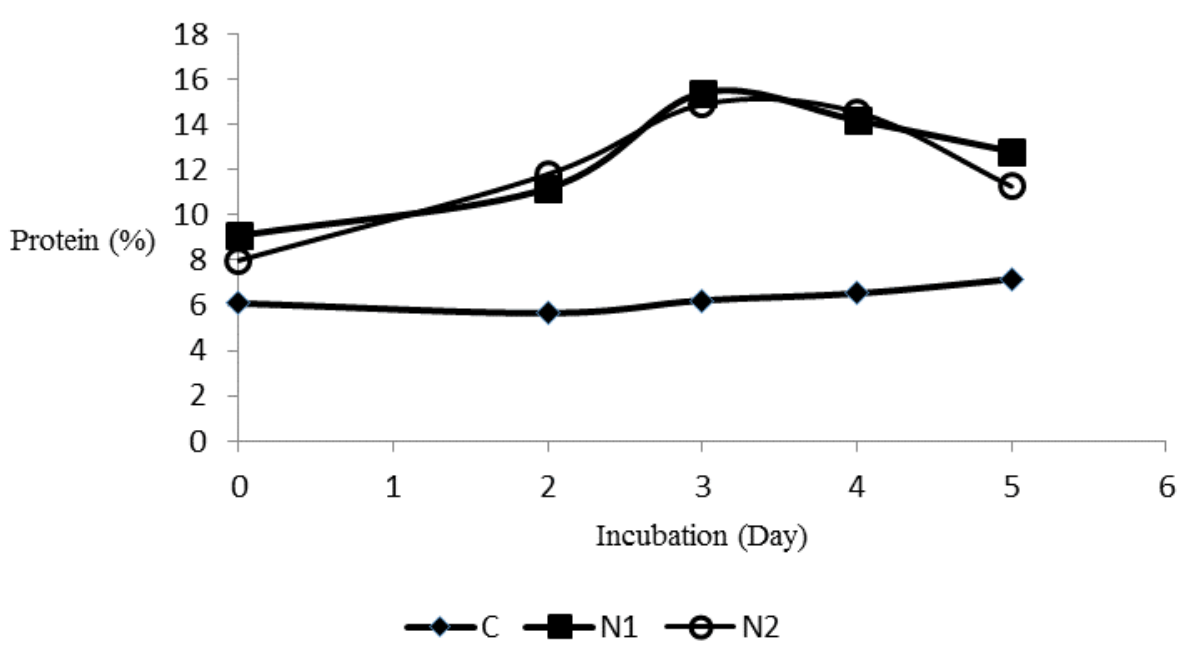

Figure 2. Protein profile of fermentation product (Statistic analysis was done for $3^{\text {rd }}$ and $4^{\text {th }}$ day incubation: the CP was not significantly different between $\mathrm{N} 1$ and $\mathrm{N} 2$ but significantly higher in A. oryzae than A. niger).

(AO) inoculums respectively. Growth of fungi in control treatment was detected at the $2^{\text {nd }}$ day of fermentation but for the next day onward the growth was not optimal. The slightly growth of fungi in control batch could explained on increased of crude protein (CP) content of control treatment. The CP content and other data of fermented products from the $3^{\text {rd }}$ and $4^{\text {th }}$ day of incubation period using A. niger and A. oryzae as fermentation agents were subjected to statistical analysis. Crude protein (CP) content of fermented $\mathrm{CPH}$ in N1 treatment was increased up to 140 and $205 \%$ when fermented with $A$. niger and $A$. oryzae respectively. However, another treatment (N2) was shown a lower CP increases up to 63 and $187 \%$ for $A$. niger and A. oryzae FCPH.

Crude fat was decrease significantly for $\mathrm{N} 2$ treatment (34 and $35 \%$ for A. niger and A. oryzae fermented $\mathrm{CPH}$ ) and was higher than in N1 treatment. Neutral Detergent Fiber (NDF) and ADF also decrease $13 \%$ for A.niger FCPH - N1 treatment, $26 \%$ for $A$. oryzae FCPH-N1 treatment, $29 \%$ for A. niger $\mathrm{FCPH}$ N2-treatment and 27\% AO FCPH N2 treatment. Crude fiber (CF) also decreased $42 \%$ and $55 \%$ for A.niger FCPH N1 and $A$. oryzae FCPH N1 respectively, and a lower value of decreased was detected on $\mathrm{N} 2$ treatment 
that is 36 and $46 \%$ for A. niger FCPH and A. oryzae FCPH respectively.

Rumen-pepsin dry matter digestibility is presented in Figure 4. It is clearly shown that fermented product of $\mathrm{CPH}$ have higher DM digestibility when compared to control. And A. oryzae FCPH both $\mathrm{N} 1$ and $\mathrm{N} 2$ treatments showed a higher DMD value than $A$. niger FCPH. The same pattern is also shown for rumenpepsin protein digestibility (Figure 5). Rumen-pepsin protein digestibility of $A$. oryzae FCPH N1 treatment was closed to the protein digestibility of King grass that was run at the same time as a comparison.

Cocoa pod husks utilization for poultry is constrained by the high content of fiber, including lignin $(14 \% \mathrm{w} / \mathrm{w})$ and non-starch polysaccharides (NSPs) such as hemicellulose $(110 \mathrm{~g} / \mathrm{kg})$, cellulose $(350$ $\mathrm{g} / \mathrm{kg}$ ) and pectin $(60 \mathrm{~g} / \mathrm{kg}$ ) (Alemawor et al. 2009) and need enzyme fortification to increase digestibility. Fermentation using Aspergillus niger showed a superiority in term of mannanase and cellulase enzymes production (Figures 6 and 7) when compared to Aspergillus oryzae. Mannanase activy in A. niger $\mathrm{FCPH}$ $\mathrm{N} 1$ treatment reached up to $2654 \mathrm{U} / \mathrm{gDM}$ and $A$. oryzae FCPH N1 was only 1122 U/gDM. Cellulase activity was lower than mannanase, for AN FCPH N1 treatment reached $1255 \mathrm{U} / \mathrm{gDM}$. Fermentation process increased nutrients composition and digestibility of $\mathrm{CPH}$

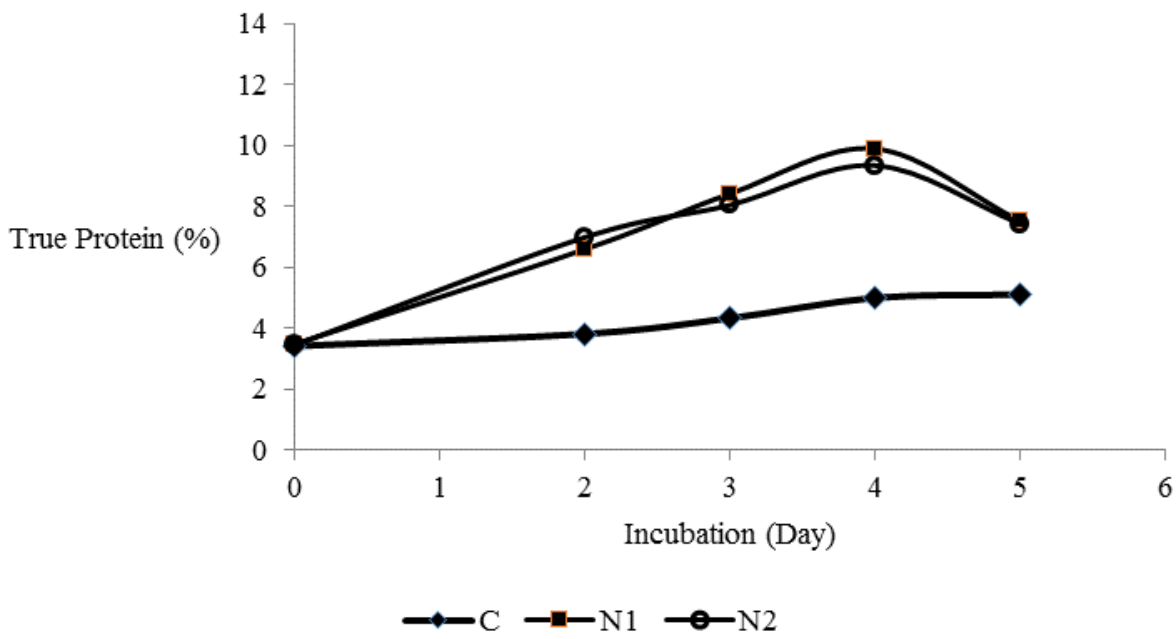

A. oryzae

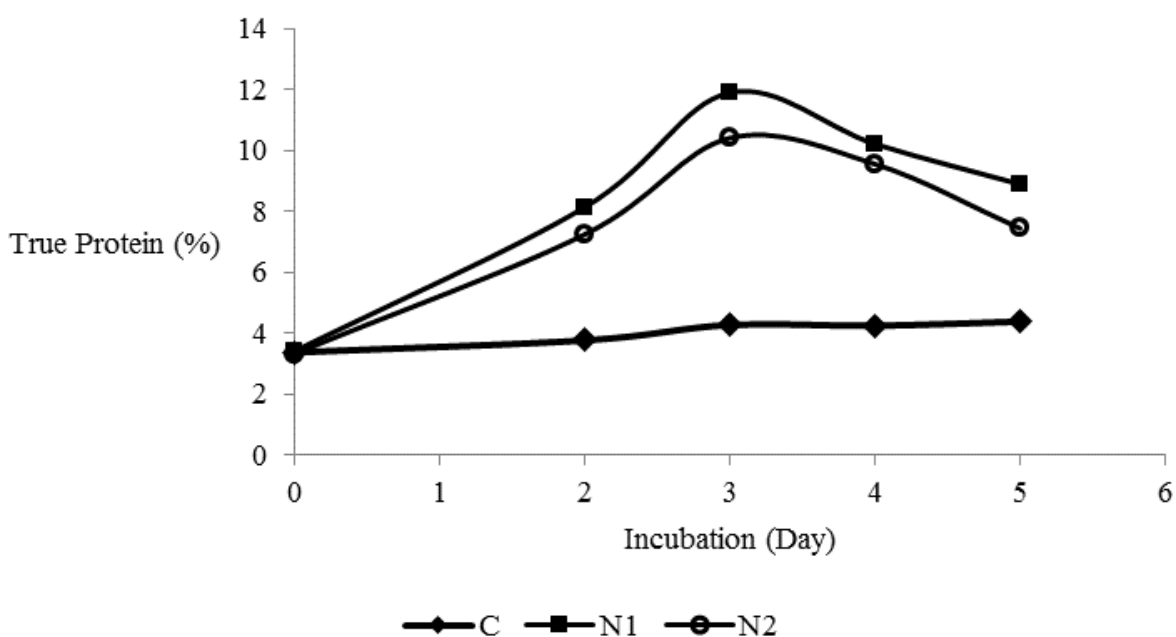

Figure 3. True Protein content of A. niger and A. oryzae fermentation product. 
Table 3. Proximate analysis of fermented $\mathrm{CPH}$ at specific day of incubation (unit in $\mathrm{g} / \mathrm{Kg}$ except it is stated)

\begin{tabular}{|c|c|c|c|c|c|c|c|c|c|c|c|c|c|c|}
\hline \multirow{3}{*}{ Composition } & \multicolumn{6}{|c|}{ Control } & \multicolumn{4}{|c|}{ N1 } & \multicolumn{4}{|c|}{$\mathrm{N} 2$} \\
\hline & \multicolumn{2}{|c|}{ D0 } & \multicolumn{2}{|c|}{ D3 } & \multicolumn{2}{|c|}{ D4 } & \multicolumn{2}{|c|}{ D0 } & \multirow{2}{*}{$\begin{array}{c}\text { D4 } \\
\text { A.nig }\end{array}$} & \multirow{2}{*}{$\frac{\text { D3 }}{\text { A.ory }}$} & \multicolumn{2}{|c|}{ D0 } & \multirow{2}{*}{$\begin{array}{c}\mathrm{D} 4 \\
\text { A.nig }\end{array}$} & \multirow{2}{*}{$\begin{array}{c}\mathrm{D} 3 \\
\text { A.ory }\end{array}$} \\
\hline & A.nig & A.ory & A.nig & A.ory & A.nig & A.ory & A.nig & A.ory & & & A.nig & A.ory & & \\
\hline Fat & 11.2 & 11.2 & 7.6 & 7.6 & 7.3 & 7.3 & 9.2 & 9.2 & 7.8 & 8.6 & 11.2 & 11.4 & 7.4 & 7.4 \\
\hline Ash & 99.3 & 99.3 & 98.4 & 98.4 & 102.9 & 102.9 & 112.9 & 112.9 & 104.4 & 104.4 & 114.5 & 115.7 & 119.3 & 119.3 \\
\hline $\mathrm{CF}$ & 518.4 & 519.0 & 517.6 & 553.7 & 543.2 & 542.9 & 517.8 & 526.7 & 302.0 & 234.6 & 513.3 & 542.1 & 328.0 & 289.8 \\
\hline $\mathrm{GE}(\mathrm{Kkal} / \mathrm{kg})$ & 3,870 & 3,857 & 3,844 & 3,832 & 3,848 & 3,838 & 3,849 & 3,837 & 3,805 & 3,795 & 3,756 & 3,618 & 3,770 & 3,770 \\
\hline NDF & 652.0 & 652.0 & 651.3 & 641.3 & 666.2 & 643.2 & 650.0 & 650.2 & 565.8 & 482.5 & 667.8 & 653.7 & 473.2 & 476.8 \\
\hline $\mathrm{ADF}$ & 621.3 & 621.3 & 631.8 & 631.6 & 641.5 & 641.0 & 611.1 & 612.0 & 482.3 & 497.7 & 622.8 & 623.4 & 416.5 & 416.5 \\
\hline $\mathrm{Ca}$ & 3.6 & 3.8 & 4.8 & 4.8 & 4.5 & 4.6 & 7.2 & 7.7 & 4.9 & 5.0 & 6.6 & 6.5 & 6.5 & 6.5 \\
\hline $\mathrm{P}$ & 1.8 & 1.8 & 1.8 & 1.8 & 1.6 & 1.6 & 2.3 & 2.2 & 1.9 & 1.9 & 1.8 & 1.8 & 2.3 & 2.3 \\
\hline
\end{tabular}

A.nig= Aspergillus niger; $\mathrm{A}$. ory=Aspergillus oryzae; $\mathrm{CP}=$ crude protein; $\mathrm{CF}=$ crude fiber; $\mathrm{GE}=\mathrm{Gross}$ energy; $\mathrm{NDF}=$ neutral detergent fiber; $\mathrm{ADF}=$ acid detergent fiber 


\section{A. niger}

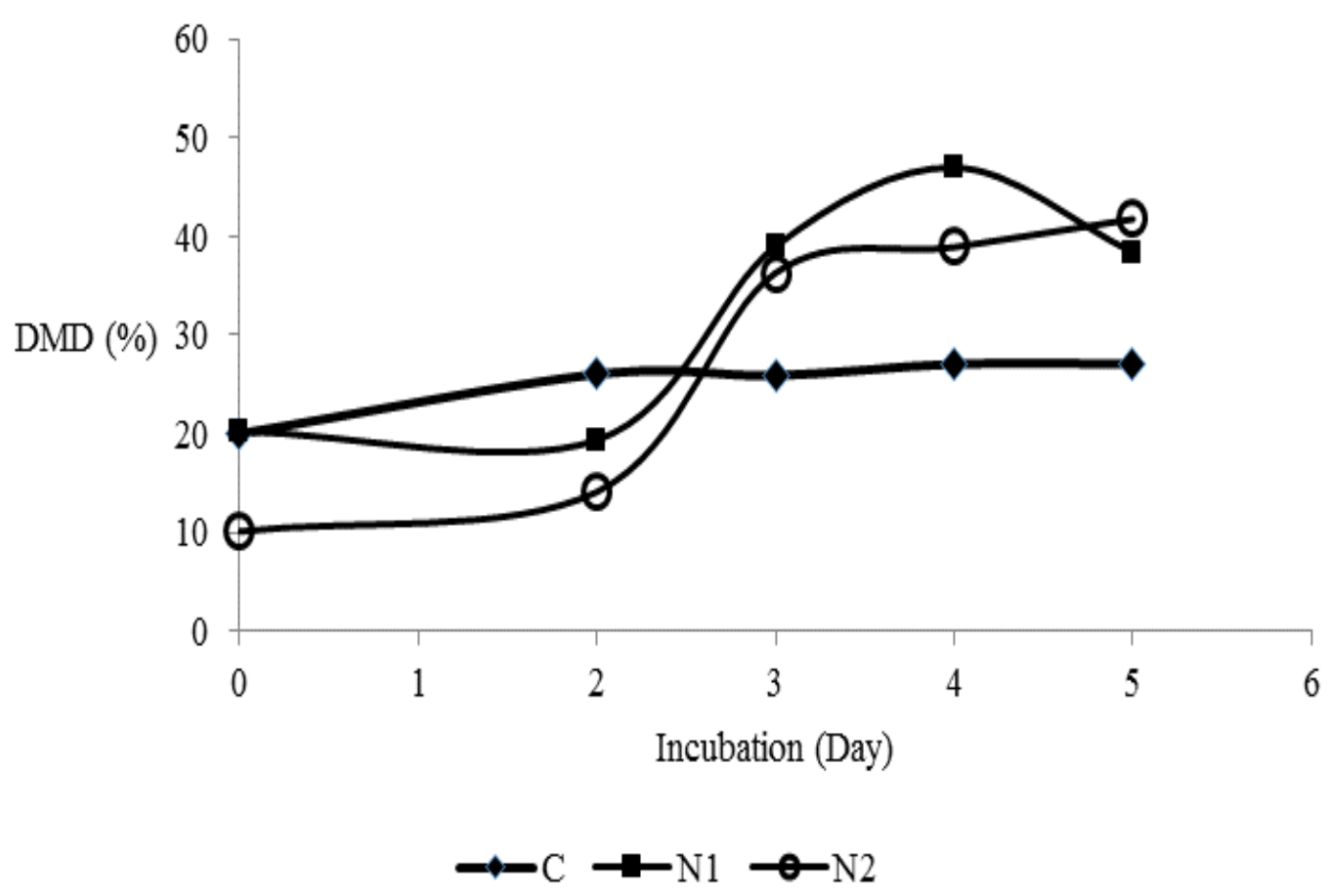

\section{A. oryzae}

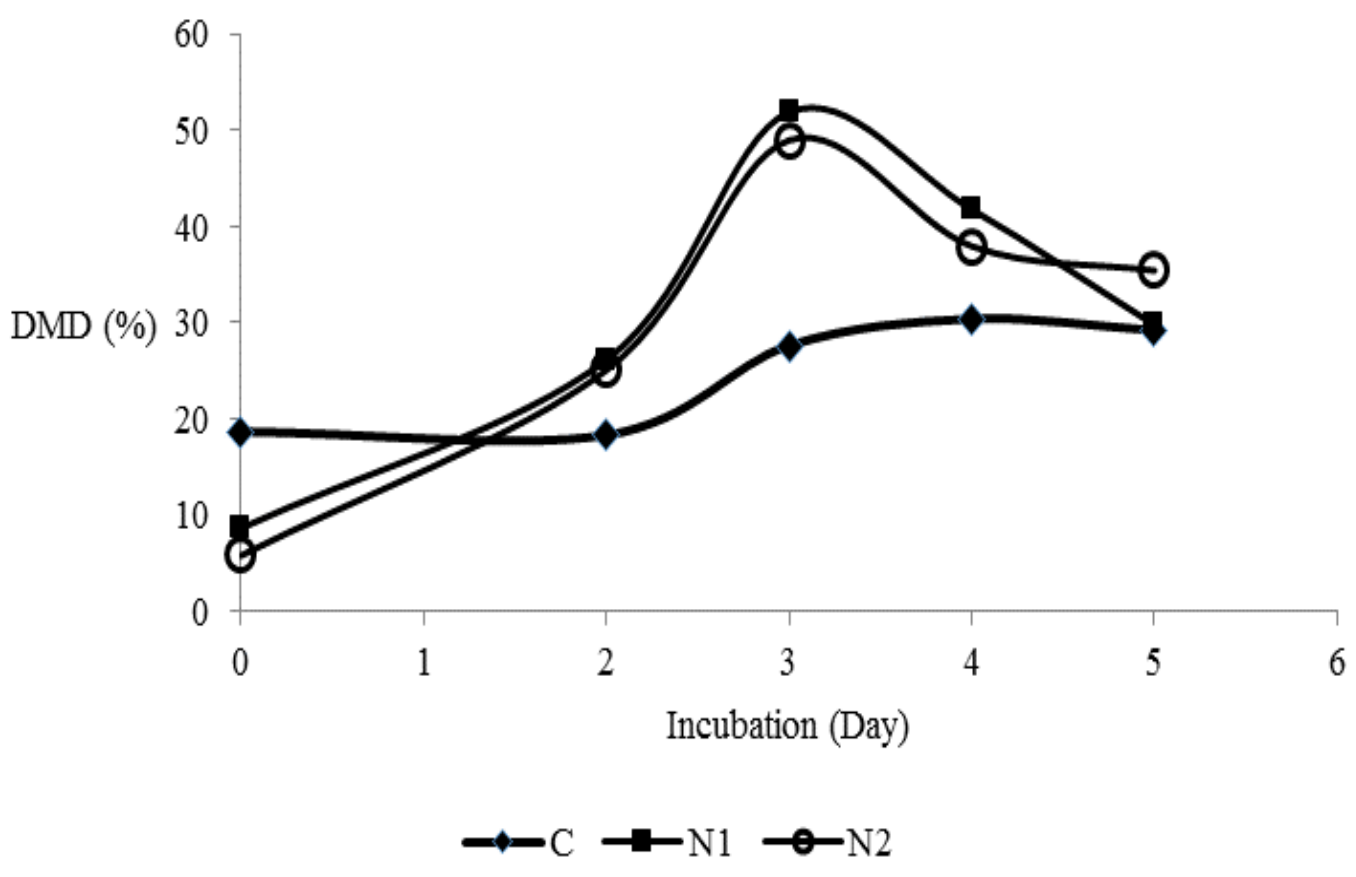

Figure 4. Dry matter digestibility of FCPH after rumen-pepsin in vitro. 


\section{A. niger}

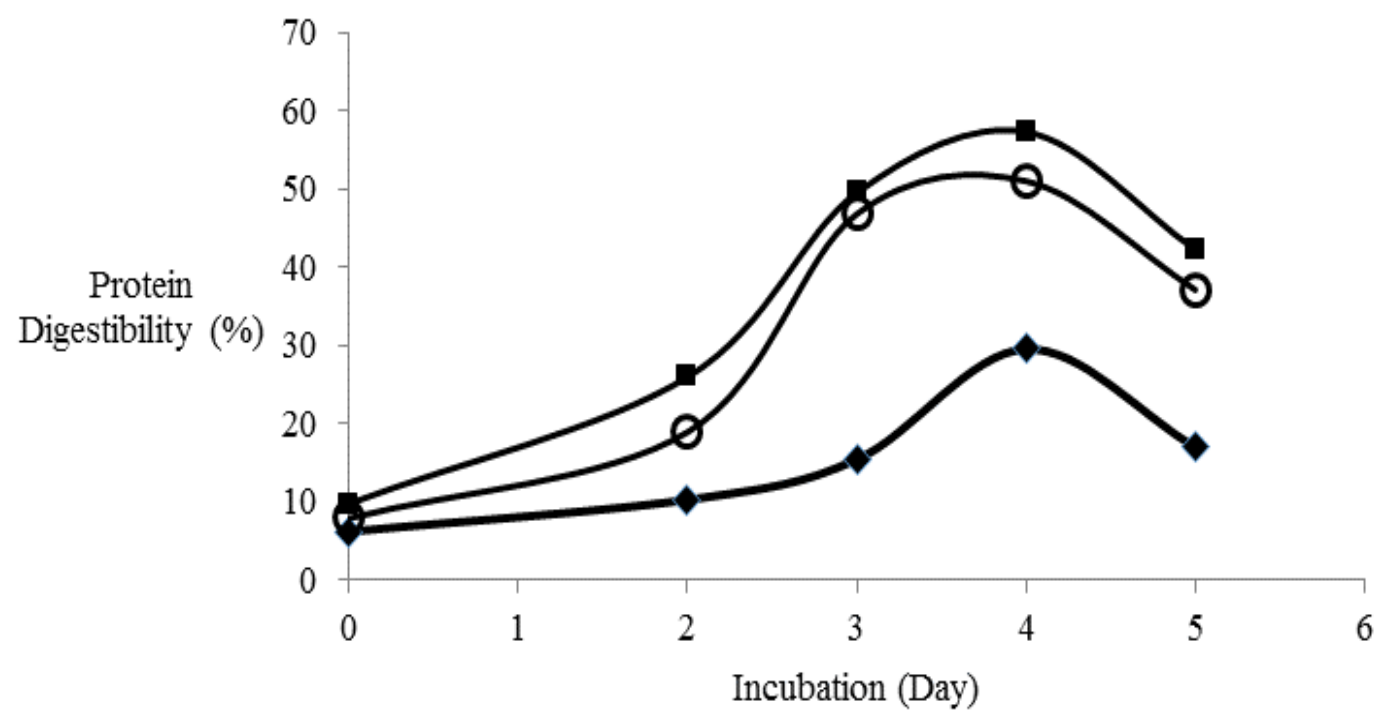

$\rightarrow$ average $\mathrm{C} \rightarrow$-average N1 $\rightarrow$ average N2

A. oryzae

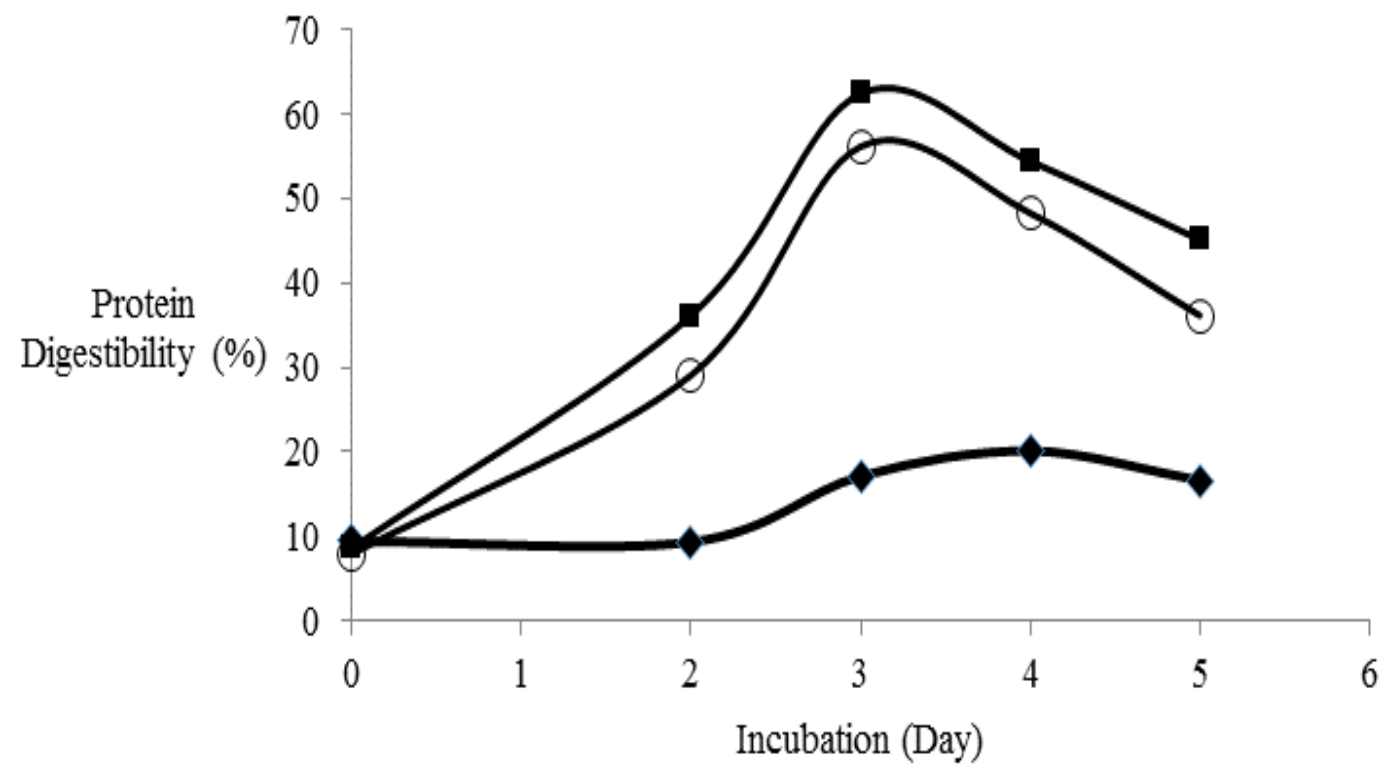

$\longrightarrow$ average $\mathrm{C} \rightarrow$ average $\mathrm{N} 1 \multimap$ average $\mathrm{N} 2$

Figure 5. Protein digestibility in vitro rumen-pepsin of FCPH. 

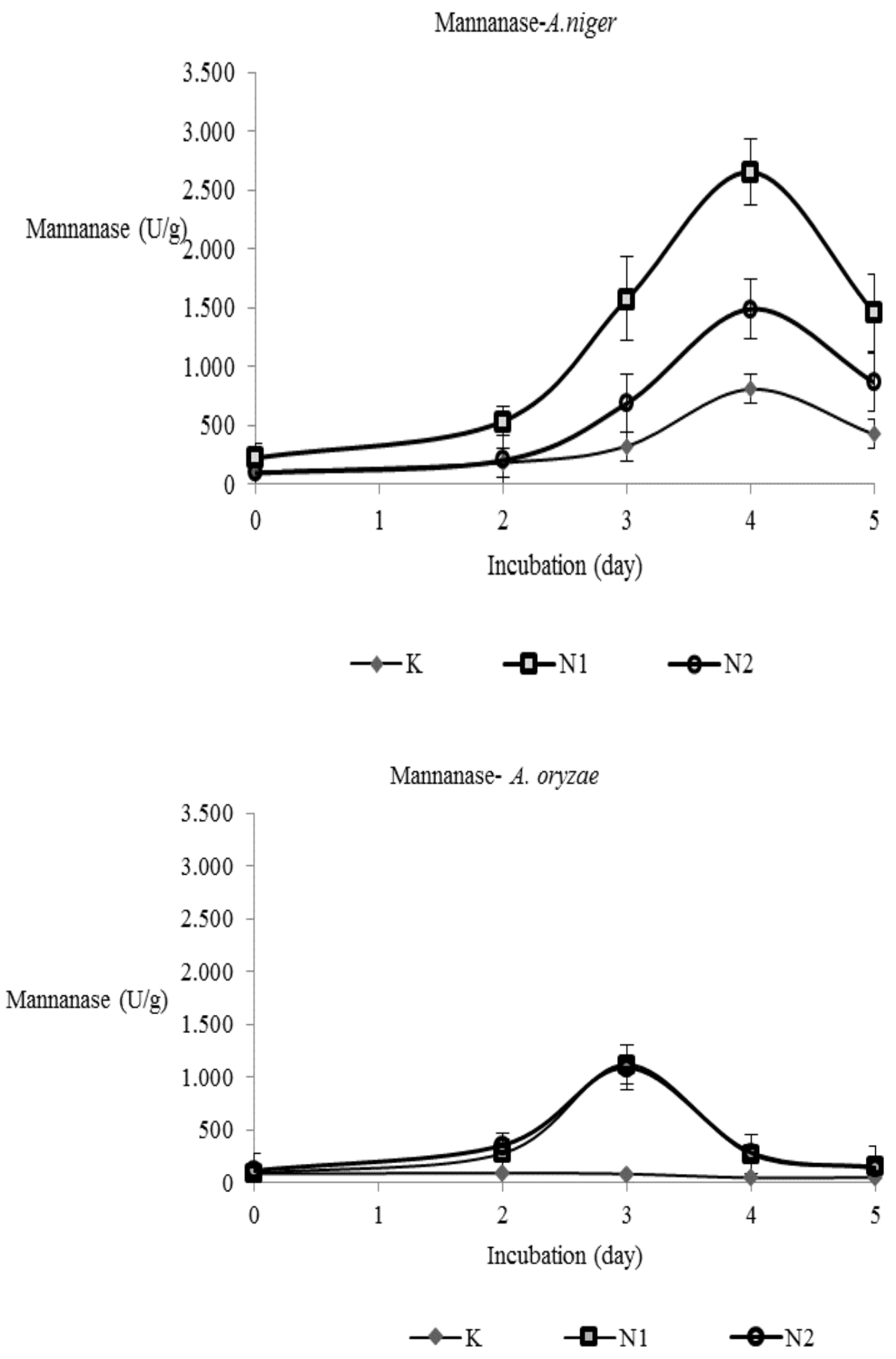

Figure 6. Mannanase activity in fermentation products. 


\section{A. niger}

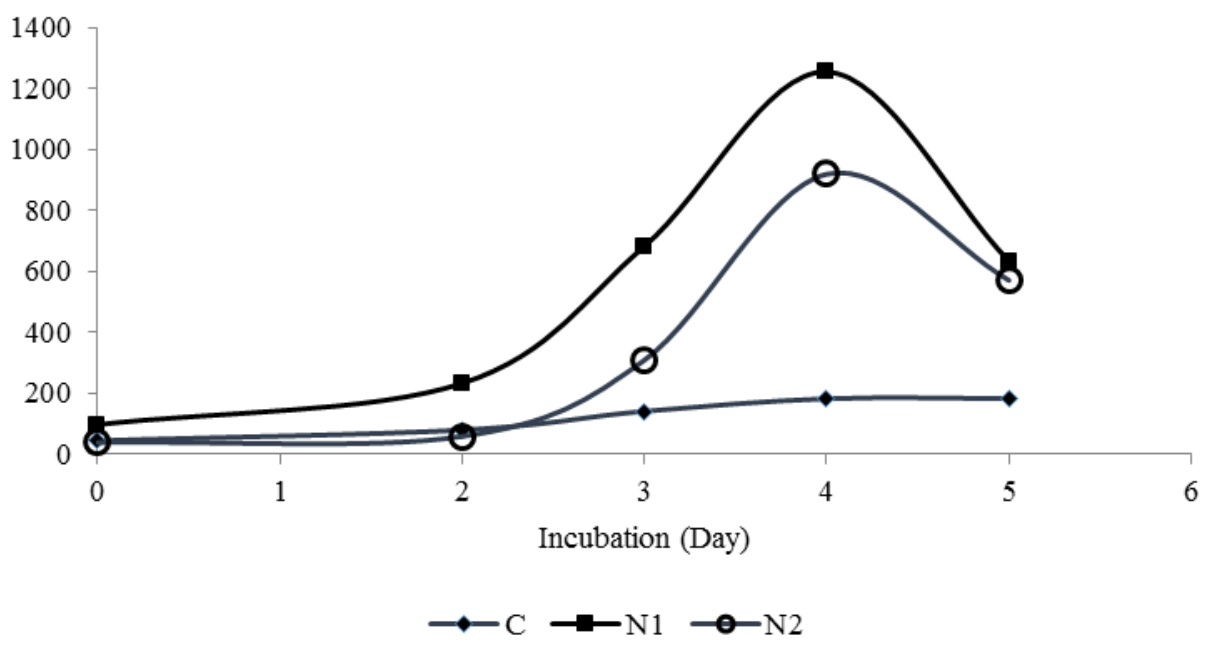

A. oryzae

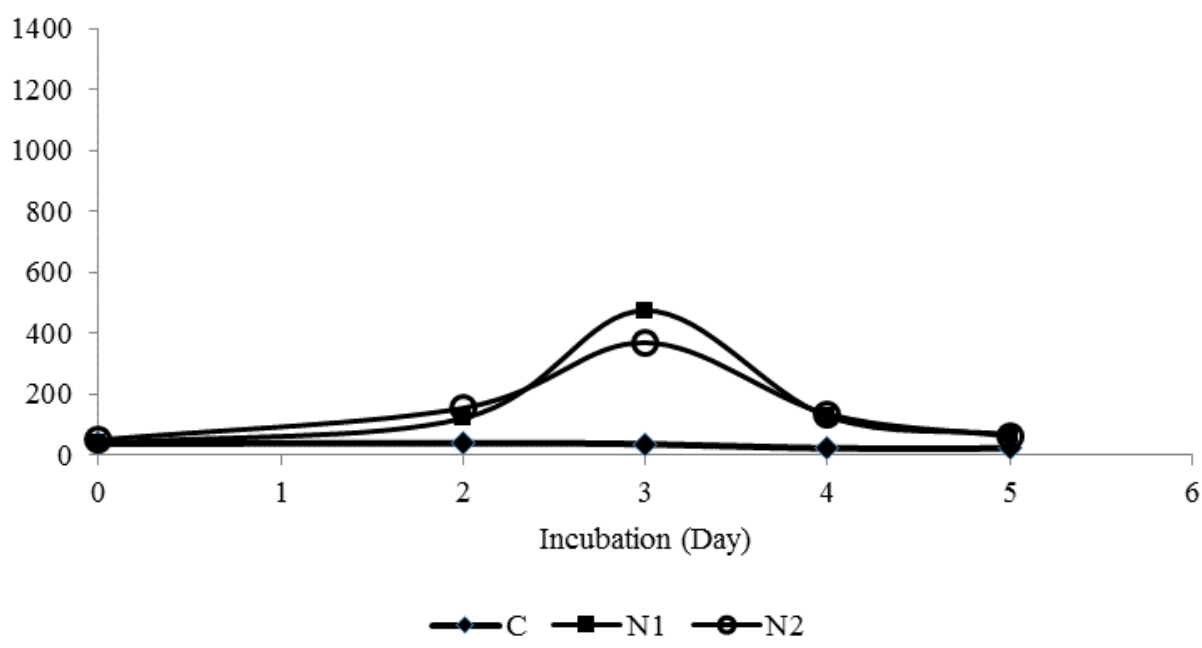

Figure 7. Cellulase activity in fermentation products.

\section{CONCLUSION}

The Nutritive value cocoa pod husk can be improved through fermentation using A. niger and $A$. oryzae. It was an increased in protein content and decreased in fiber fractions (crude fiber, NDF and ADF). Mannanase and cellulase content also contributed for increasing in digestibility. Fermentation product of $\mathrm{CPH}$ is very potential as an alternative feed for mitigation in feed shortage.

\section{ACKNOWLEDGEMENT}

This study was funded by the Indonesian government (APBN 2011). The authors thank all the technicians (Mrs. Emma Ludia and Mrs, Emi Sujatmika) who helped in preparation of samples and doing laboratory analyses. We also express our appreciation to Romaulina Yohana Septiani (AKA Bogor Polytechnic) who took part in this research activity. 


\section{REFERENCES}

Alemawor F, Dzogbefia VB, Emmanuel OK, James HO. 2009. Enzyme cocktail for enhancing poultry utilization of cocoa pod husk. Francis Sci Res Essay. 4:555-559.

Chalall DS. 1985. Solid-substrate fermentation with Trichoderma reseei for cellulase production. Appl Env Microbiol. 49:205-210.

Elmakeel EA, Titgemeyer EC, Johnson BJ, Armendariz CK, Shirley JE. Fibrolytic enzymes to increase the nutritive value of dairy feedstuffs. J Dairy Sci. 90:5226-5236.

[FAO] Food and Agricultural Organization. 2002. Animal feed resources information system. USA: Food and Agricultural Organization. p. 76-82.

Haryati T, Sutikno I. 1994. Peningkatan nilai nutrisi kulit biji coklat melalui bioproses menggunakan beberapa jenis kapang. Ilmu Peternakan. 8:34-37.

Iyayi EA, Aderolu ZA. 2004. Enhancement of the feeding value of some agro-industrial by-products for laying hens after their solid state fermentation with Trichoderma viride. Afr J Biotechnol. 3:182-185.

Iyayi EA. 2004. Changes in the cellulose, sugar and crude protein contents of agro-industrial by-products fermented with Aspergillus niger, Aspergillus flavus and Penicillium sp. Afr J Biotechnol. 3:186-188.

Kompiang IP. 1994. Cassapro, a promising protein enriched cassava as animal and fish feed. Indones Agric Res Develop J. 16:57-63.

Lateef A, Oloke JK, Gueguim Kana EB, Oyeniyi SO, Onifade OR, Oyeleye AO, Oladosu OC, Oyelami AO. 2008. Improving the quality of agro-wastes by solid-state fermentation: Enhanced antioxidant activities and nutritional qualities. World J Microbiol Biotechnol. 24:2369-2374.

Leifa F, Padey A, Soccol CR. 2001. Production of Flammulina velutipes on coffee husk and coffee spendground. Braz Arch Biol Tech. 44:205-212.

Lowry OH, Rosebrough NJ, Farrand AL, Randall RJ. 1951. Protein measurement with the Folin phenol reagent. J Biol Chem. 193:265-275.

Marais JP, Evenwell TK. 1983. The use of trichloroacetic acid as precipitant for the determination of 'true protein' in animal feeds. S Afr J Anim Sci. 13:138-139.
Mekala NK, Singhania RR, Sukumaran RK, Pandey A. 2008. Cellulase production under solid state fermentation by Trichoderma reesei RUT C30: Statistical optimization of process parameters. Appl Biochem Biotechnol. 151:122-131.

Miller GL. 1959. Use of dinitrosalicylic acid reagent for determination of reducing sugar. Anal Chemist. 31:426428 .

Purwadaria T, Haryati T, Darma J. 1994. The development of inoculum production of Aspergillus niger for cassapro fermentation. Proceeding Seminar on National Science and Technology of Animal Husbandry. Bogor (Indones): Indonesian Research Institute for Animal Production.

Purwadaria T, Nirwana N, Ketaren PK, Iswantini D. 2003. Synergistic activity of enzymes produced by Eupenicillium javanicum and Aspergillus niger NRRL 337 on palm oil factory wastes, Biotropis. 20:1-10.

Singhania RR, Sukumaran RK, Pillai A, Prema P, Szakacs G, Pandey A. 2006. Solid-state fermentation of lignocellulosic substrates for cellulase production by Trichoderma reesei NRRL 11460. Indian J Biotechnol. 5:332-336.

Smith OB, Adegbola AA. 1985. Studies on the feeding value of agro-industrial by-products. III. Digestibility of cocoa-pod and cocoa-pod-based diets by ruminants. Anim Feed Sci Technol. 13:249-254.

Sobamiwa O, Longe OG, 1993. Utilization of cocoa pod pericarp fractions in broiler chick diets. Anim Feed Sci Technol. 44:237-244.

Sobamiwa O. 1998. Performance and egg quality of laying hens fed cocoa husk based diets. Nigeria J Anim Prod. 25:22-24.

Swe KH, Alimon AR, Ramin M. 2009. Effect delaying sporulation by addition of ammonium sulphate on the fermentation of palm kernel cake based subtrate by Aspergillus niger. Am J Agric Biol Sci. 4:262-265.

World Cocoa Foundation. 2010. In: FAOstat, cocoa market update. Published repports and ressources ed. Washington DC (USA): Food and Agricultural Organization. 